\title{
Islamic Views on Money Politic Practices in the Constitutional Election of 2019
}

\section{Karto*) and Akhmad Khisni}

*) Student of Masters (S2) of Law Faculty of Law Unissula and Bawaslu of Pati Regency, Email:kartohaidar@gmail.com

**) Lecturer of Master of Law, Faculty of Law, Universitas Islam Sultan Agung (UNISSULA) Semarang

\section{Abstract.}

The purpose of this research is to find out and analyze the reasons for the still widespread practice of money politics in the 2019 simultaneous elections. Research methods this uses a normative juridical method, in the form of legal materials written in documents. Which then analyzed qualitatively using the theory of legal certainty and law enforcement. The results of this study are: First, the reasons for the practice of money politics in the 2019 simultaneous elections are known. Second, the view of Islamic law in tackling the practice of money politics/Riswah in the upcoming simultaneous elections. The conclusion in this paper, the causes of money politics include: weak faith, low political education, economic/poverty factors, weak laws, cultural habits and traditions, weak supervision, low education, the last factor is distrust of public figures. View of Islamic Law. Returning to the teachings of Allah is the single most effective way to prevent the practice of money politics, among others, Faith in Allah, people who have faith will be afraid to commit prohibited actions such as bribery, corruption and others, then act, Honest, trustworthy and istiqomah, people. who are able to embody this behavior then the path will be straight, fair, blessed, grateful and qona'ah, if you really return to the concept of Islam, you will not dare to practice money politics.

Keywords: Islamic; Views; Money Politics; Elections.

\section{Introduction}

Money politics or money politics still occurs from election to election. Money politics is a real threat to the Indonesian nation's efforts to achieve clean, integrity and dignified elections. This is because the practice of money politics makes political costs expensive.

In the end, money politics will encourage corrupt behavior because political actors certainly want the capital they spent to return. To be able to foster a healthy democracy, Indonesia as a nation must jointly fight against money politics, this negative behavior must be made a common enemy because it has been proven to damage the foundations of the nation's life. We can only realize a healthy democracy if the elections and regional elections are clean money politics. 1

Even though the money politic perpetrators are not half-heartedly

\footnotetext{
1 Abhan. (2019). Melawan Money politic Catatan Pengawas Pemilu 2019. Prolog of head of Bawaslu RI, Bawaslu Reg. Magelang. p. vii
} 
sanctioned in Article 73 paragraph (4), they are punished with imprisonment of at least 36 (thirty six) months and a fine of at least IDR 200,000,000 (two hundred million rupiah) and a maximum of IDR 1,000,000,000 (one billion rupiah). ${ }^{2}$

Muhammad Arwani Thomafi, deputy chairman of Commission II DPRRI highlighted that such a direct Regional Election is supposed to uphold people's sovereignty but what happens is the strength of capital sovereignty, the direct Regional Election actually provides room for capital-intensive candidates to appear in contestation. ${ }^{3}$

Election means realizing people's sovereignty in the country in the framework of people's participation in running state governance, not only aiming to elect representatives who will sit in consultative/representative institutions, but also as a means of realizing the preparation of state livelihoods imbued with the spirit of Pancasila and the Basic Law. 1945 in the Unitary State of the Republic of Indonesia. ${ }^{4}$

On April 17, 2019, Indonesia held a Concurrent Election for the first time in the history of elections in Indonesia, namely the Presidential/Vice Presidential Election which was held simultaneously with the Legislative Election (Election to elect Members of DPR, DPD, Provincial DPRD and Regency/City DPRD) .

The general election is the process of selecting the President and Vice President, members of DPR, DPD, DPRD directly by the people, which is carried out simultaneously for all candidates for members of the legislative and executive assemblies whose term of office ends in the same year. So the state will do it simultaneously and be done throughout Indonesia. ${ }^{5}$

An election is never separated from the name of the election organizer. An Election Administrator is an institution that organizes Elections consisting of the General Election Commission, Election Supervisory Body, and the Honorary Council of Election Administrators as a unitary function of Election Administration to elect members of the People's Representative Council, members of the Regional Representative Council, President and Vice President, and to elect members of the Regional People's Representative Council directly by the people 6

MUI (Indonesian Ulama Council) states that the law of money politics (Riswah) in Islam is haram, committing corruption is also haram as stated in the fatwa decision of the Indonesian Council of Ulama (MUI) number: 4/Munas VI/MUI/2000 regarding Riswah (bribery) of Ghulul (corruption) ) and gifts to

\footnotetext{
${ }^{2}$ Article 187 A paragraph (1) of Act No. 10, 2016, concerning Regional Head Elections.

3 Thomafi, Arwani. (2020). 100 Tokoh Inspirasi Jawa Tengah. Central Java Tabloid. Edition, Publisher Citra. p.314

4 Sri Herlina and Umar Ma'ruf, Law Enforcement Against Election Crime During the 2019 Election Campaign (Case Study at Bawaslu Banjarmasin City) Journal of Daulat Hukum Volume 2 Issue 3, September 2019. p. 299

5 http://jom.untidar.ac.id/index.php/lontarmerah/article Rizky Agung Adi Prasetyo, Zulfikar Ranu Sasmita. Accessed June 29, 2020

6. Act No. 7 of 2017 concerning General Election article 2 point 7
} 
officials. ${ }^{7}$

Allah will curse the perpetrator of bribery, as the Prophet SAW said: From Abu Hurairah RA said: Rasul SAW said: Allah SWT curses bribes and those who are bribed. ${ }^{8}$ The warning from Rasulullah SAW is even stricter, in the narration of AtThabrani: "From Abdillah bin Amr has said: Rasulullah saw. has said: One who bribes and is bribed in (enters) hell. " (HR. At-Thabrani). ${ }^{9}$

Starting from the problems mentioned above, the author would like to discuss in more detail about this money politics as a contribution and what steps can stop the contestants from practicing money politics, and offer solutions for solutions so that in the future this practice will not It happens again.

\section{Research Methods}

In this study the authors used a normative juridical method. Specification research used is descriptive analytical, which describes the applicable laws and regulations in relation to legal theories and their implementation practices. ${ }^{10}$ Primary and secondary data sources obtained by interview and study document methods. Data analysis using qualitative analysis.

\section{Research Methods}

The research specification used is descriptive analytical, in this case that is related to the implementation of the duties and functions of the Bawaslu of Pati Regency as a supervisor in the general election stage, then an analysis of the results of the research is carried out using legislation and relevant theories. The collected data will be arranged in an analytical description. The data that has been obtained are then analyzed by qualitative analysis, namely data analysis by not using numbers. ${ }^{11}$ Where with this method clear data will be obtained regarding the main problem.

\section{Results and Discussion}

\subsection{The Factors of Money Politics}

There are many practices of money politics in the holding of simultaneous elections in 2019. The factors include:

a. The weak factor of faith

\footnotetext{
${ }^{7}$ Fatwa Majlis Ulama Indonesia (MUI) number: 4/Munas VI/MUI/2000 concerning Riswah (bribery) Ghulul (corruption) and gifts to officials.

${ }^{8}$ HR. Imam Ahmad. This hadith was stated as authentic by the Shaykh Al-Banani inside shohih Attarghib wa At-Tarhibno. 2212, Riyadh: Maktabah Al-Ma'arif, Volume 2. p. 529.

${ }^{9} \mathrm{HR}$ at-Thabari; al-Mu'jam al-Kabir, Beirut: al-Maktab al-Islami, volume I. p. 57.

10 Suryabrata, Sumardi. (1993). Metodologi Penelitian. Jakarta: Rajawali. p. 19

11Fajar, Mukti \& Yulianto Achmad. (2010). Dualisme Penelitian Hukum Normatif Dan Empiris. Yogyakarta: Student Library. p.153
} 
There is still a lack of commitment by officials or employees and part of the community in upholding the values of faith, for example the feeling of being watched by Allah SWT, being aware that life is temporary, and belief in calculating charity on the Day of Judgment, how is life in the hereafter that is not limited, torture is very crazy and unceasingly for sinners, including those who practice money politics. Faith is like a magnet, if the magnets are bigger the light, the brighter the daily life can be seen that the obligatory and sunnah worship movements that never stop being carried out, that is the influence of strong faith. ${ }^{12}$

b. Political Factors

Money politics occurs because the legislative candidates do not have a program but want to win. Meanwhile, the political parties that carry it do not play much role other than helping in the candidacy. "Here can be seen the failure of parties and candidates in building programs," competition both inside and outside the party encourages candidates to do anything, the important thing is to win.

c. Low Political Education Factors

Subjects who lack political education, both candidates and voters (society), are still very minimal in political education. Many people have or do not believe in candidates. Because of that the candidate chose to use the money to restore public attention and trust back.

d. Economic factors/poverty

Poverty has so far made people think rationally about getting a number of benefits, including when receiving rewards given by political candidates or contestants in elections. The practice of money politics is not easy to prevent and stop if economic limitations and poverty still afflict our society.

e. Legal Factors

Weak regulations regarding money politic in this year's election is a setback when compared to the Regional Election. He compared one of the points, the Regional Election, the giver and the recipient.

f. Cultural Factors Customs and Traditions

There is a custom that has been entrenched in Indonesia, namely it is inappropriate to refuse gifts and to be accustomed to repaying gifts. This cultural instrument is used by politicians to carry out money politics. Money politics in the grassroots democratic process (grass root) thrives because it is considered normal and always occurs from election to election.

g. The weak factor of supervision

This factor is due to the very limited number of election supervisors who have to supervise election participants, the number of which is not comparable, Bawaslu RI numbering 5 people, Province 5 to 7 people, City regency 3 to 5 people in District 3 people at each TPS. 1 person, so without community participation, this supervision would not be optimal

h. Low education

\footnotetext{
${ }^{12}$ Abdul Azis. (2020). Mahfudhat Fadhlailul Iman, Intelligent with the Mat method. Malang. p.1
} 
Factors of Low Education The cause of the low quality of education ultimately causes people to have low knowledge of politics and the violations that occur in elections. This public's ignorance affects their behavior in responding to the practice of money politics, this can be seen from the ease with which the community accepts a number of rewards.

i. The factor of distrust in public figures

There is also a lack of leadership figures who can be emulated and used as role models so that people think that whoever becomes the leader will not be able to change their fate, which in turn makes the community buy and sell votes for the parties concerned.

\subsection{The View of Islamic Law on Practices of Money Politic/Riswah}

Money politics or Riswah Apart from being prohibited by the constitution, this practice is also strongly opposed by religion. Islam strictly prohibits money politics. Majlis Ulama Indonesia (MUI) with its fatwa that the law of money politics (Riswah) in Islam is haram, committing corruption is also haram as the fatwa decision of the Indonesian Ulama Council (MUI) number: 4/Munas VI/MUI/2000 on Riswah (bribery) Ghulul (corruption) and gifts to officials.

Islam strictly prohibits this kind of money politics practice. Money politics is the same as Riswah or bribes, Allah's warning not to eat false assets as stated in Surah al-Baqarah verse 188, Allah says: "And do not consume one another's wealth unjustly or send it [in bribery] to the rulers in order that [they might aid] you [to] consume a portion of the wealth of the people in sin, while you know [it is unlawful]."13

Allah's warning in this verse is clear that we are prohibited from eating property in a false way, the practice of money politics/Riswah is a bribery transaction which is said to be false which is prohibited by Allah.

In another word Allah instructs us all to always uphold the truth: "O you who have believed, be persistently standing firm for Allah, witnesses in justice, and do not let the hatred of a people prevent you from being just. Be just; that is nearer to righteousness. And fear Allah; indeed, Allah is Acquainted with what you do." (Surah Al-Maidah: 8). ${ }^{14}$

From the description above, gnats are spared from the practice of money politics:

a. Faith in Allah

Namely that the rules of Allah apply to the safety of life in this world and the hereafter. Believe that Islam, the Koran will save us. This belief must be 100 percent, there is no doubt. If you are sure, then there must be evidence of surrendering yourself, to be regulated in all matters without exception.

b. Honest, trustworthy and istiqomah

Honest, trustworthy and istiqomah deeds are very well applied in everyday life.

${ }^{13}$ Al-Quran Translated, Ministry of Religion, p. 36

14 Ibid., p. 144 
Honest means what is said according to what is done. While amanah means trustworthy. As for istiqomah, it means being steadfast in your stance or being consistent in your actions. 15

c. Fair

Affirmed in the Al-Qur'an Surah Al-Maidah (5) verse 8: "O you who have believed, be persistently standing firm for Allah, witnesses in justice, and do not let the hatred of a people prevent you from being just. Be just; that is nearer to righteousness. And fear Allah; indeed, Allah is Acquainted with what you do."

d. Akhlaqul Karimah

Prophet Muhammad SAW is a human being who is most noble in character and is an example for all mankind, especially for believers, as Allah says in the Qur'an;

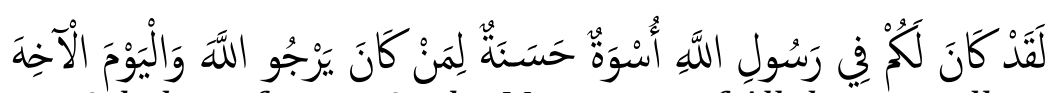

Meaning: "There has certainly been for you in the Messenger of Allah an excellent pattern for anyone whose hope is in Allah and the Last Day and [who] remembers Allah often." (Surah Al-Ahzab:21). ${ }^{16}$

Rasulullah SAW said,

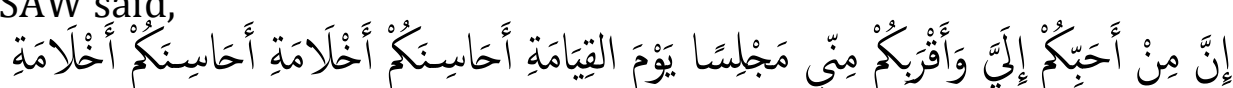
Meaning: "Surely the ones I love the most among you and the closest they sit to me on the Day of Resurrection are those who are the best in character among you." (HR. Tirmidhi) ${ }^{17}$

e. Grateful

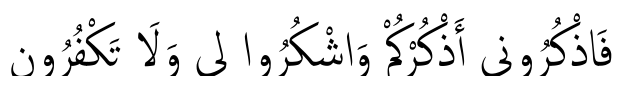

Meaning: "Then remember you to Me (Allah), I will also remember you, and be grateful to me, and don't deny, My favors. (Surgh Al-Baqarah: 152). ${ }^{18}$

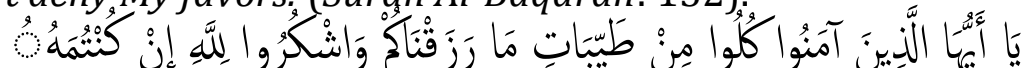

Meaning: " O you who have believed, eat from the good things which We have provided for you and be grateful to Allah if it is [indeed] Him that you worship." (Surah Al-Baqarah: 172) ${ }^{19}$

f. Qona'ah

Qana'ah means feeling pleased or sufficient for what Allah has bestowed. There are many propositions, either the Qur'an or the Sunnah, which instruct believers to apply qona'ah in receiving gifts from Allah. And this quality should always exist in a believer. The Prophet (pbuh.) said:

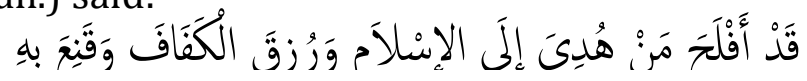

Meaning: "It is fortunate that people who are given guidance in Islam, are given sufficient rizki, and qana'ah (feel sufficient) with this rizki." (Narrated by Ibn Majah no. 4138, Shaykh Al Albani said that this hadith is authentic). ${ }^{20}$

\footnotetext{
15 Brainly.co.id - https://brainly.co.id/tugas/727048\#readmore

16 Op.Cit. 595

17 HR. Tirmidhi no. 1941. Assessed as hasan by Al-Albani in Sahih Al-Jaami 'no. 2201

18 Op.Cit. Surah Al-Baqarah: 152

19 Op. Cit, p. 32

${ }^{20}$ Narrated by Ibn Majah no. 4138, Shaykh Al Albani said that this hadith is authentic
} 
Rasulullah Sallahu'alaihi Wasalam said: "Look at those who are below you and do not pay attention to those who are above you. It is more appropriate for you to have such a character so that you do not underestimate the blessings that Allah has bestowed (Abu Mu'awiyah added - to you)." (Narrated by Ibn Majah no. 4138, shahih said by Shaykh Al Albani). ${ }^{21}$

\section{Conclusion}

Returning to the teachings of Allah is the single most effective way to prevent the practice of money politics, among others, true faith in Allah, people who have faith will be afraid to commit prohibited actions such as bribery, corruption etc., then act honestly, trustworthy and istiqomah, people who able to embody this behavior then the path will be straight, then fair, blessed, be grateful and qona'ah, if we return to the Islamic concept, the prohibition on money politics will be abandoned.

\section{References}

Journal:

[1] Sri Herlina and Umar Ma'ruf, Law Enforcement Against Election Crime During the 2019 Election Campaign (Case Study at Bawaslu Banjarmasin City) Journal of Daulat Hukum Volume 2 Issue 3, September 2019

Books:

[1] Al-Quran Translated, Ministry of Religion

[2] Abdul Azis. (2020). Mahfudhat Fadhlailul Iman, Intelligent with the Mat method. Malang

[3] Abhan. (2019). Melawan Money politic Catatan Pengawas Pemilu 2019. Prolog of head of Bawaslu RI, Bawaslu Reg. Magelang

[4] Fajar, Mukti \& Yulianto Achmad. (2010). Dualisme Penelitian Hukum Normatif Dan Empiris. Yogyakarta: Student Library

[5] HR at-Thabari; al-Mu'jam al-Kabir, Beirut: al-Maktab al-Islami, volume I

[6] HR. Imam Ahmad. This hadith was stated as authentic by the Shaykh AlBanani inside shohih At-targhib wa At-Tarhibno. 2212, Riyadh: Maktabah AlMa'arif, Volume 2

[7] HR. Tirmidhi no. 1941. Assessed as hasan by Al-Albani in Sahih Al-Jaami' No. 2201

[8] Ibn Majah no. 4138, Shaykh Al Albani said that this hadith is authentic

[9] Suryabrata, Sumardi. (1993). Metodologi Penelitian. Jakarta: Rajawali

[10] Thomafi, Arwani. (2020). 100 Tokoh Inspirasi Jawa Tengah. Central Java Tabloid. Edition, Publisher Citra

Regulations:

${ }^{21}$ HR. Ibn Majah no. 4138 
[1] Article 187 A paragraph (1) of Act No. 10, 2016, concerning Regional Head Elections.

[2] Act No. 7 of 2017 concerning General Election article 2 point 7

[3] Fatwa Majlis Ulama Indonesia (MUI) number: 4/Munas VI/MUI/2000 concerning Riswah (bribery) Ghulul (corruption) and gifts to officials. Abhan, 2019, Against Money Politics 2019 Election Supervisory Notes. Prologue of the Chairman of Bawaslu RI, Bawaslu Kab. Magelang

Internet:

[1] https://id.wikipedia.org/wiki/Politik_uang

[2] http://jom.untidar.ac.id/index.php/lontarmerah/articleRizky Agung Adi Prasetyo, Zulfikar Ranu Sasmita. Accessed June 29, 2020

[3] Brainly.co.id - https://brainly.co.id/tugas/727048\#readmore 